\title{
COLLECTORS INNOVATION TO INCREASE PERFORMANCE SOLAR WATER HEATER
}

\author{
Mustafa $^{1}$, Ismail.N.R. ${ }^{2}$ \\ ${ }^{1}$ Lecture of Merdeka University, Madiun, ${ }^{2}$ Lecture of Widyagama University Malang, mustafaunmer@yahoo.co.id
}

\begin{abstract}
There have been many studies to improve the performance of the solar water heater. The long term goal of research is to obtain scientific information, teaching materials and as the foundation of scientific development of energy conversion. The specific objective of this study is to find or develop new models and models that can improve the efficiency of the solar water heater.
\end{abstract}

Research methods; research conducted using the experimental method, which is to test the amount of cover glass, flow rate and preheat a working fluid that can improve the efficiency of solar water heater.

Research output: 1) The efficiency of the best solar water heater is the sum of three layers of glass cover compared to the cover glass number two layers and one layer, 2) The greater the water flow rate, the efficiency of the solar water heater increases, 3) initial heating on water entry, exit and cause the water temperature absorber plate temperature is relatively the same, so the efficiency of the solar water heater close to zero.

Keywords: number of glass cover, flow rate, initial heating, solar water heater

\section{INTRODUCTION}

\section{Background}

According to Mustafa (2008), The efficiency of absorption of solar heat on the double plate heater is higher than the efficiency of conventional heater solar heat absorption and heat absorption efficiency of the (Ti-Ta) / Gt dual plate solar heater decline more sharply than a conventional diesel heater. Mustafa (2009), In each test variation of the flow rate on the heat absorption efficiency solar heater double plate is higher than the efficiency of absorption of solar heat and a conventional heater temperature solar water heater plate out double in the afternoon decline is slower than the temperature of the water out of conventional solar heater . Ismail (2008), examined the absorber plate absorber double and single use concrete in a simple solar water heater, solar water heater efficiencies simple dual absorber plate is higher than single absorber plate. Farid and Ismail (2010), concrete absorber plate waveform generating efficiency of solar water heater is higher than flat plate absorber.

According to Farid and Ismail (2006), the amount of glass cover three layers with a thickness of $5 \mathrm{~mm}$ produce high efficiency solar water heater is higher than using one or two layers. According Anggraini (2001), using a thickness of 3 $\mathrm{mm}$ glass solar water heater has an efficiency higher than that using a $5 \mathrm{~mm}$ glass thickness and spacing of the glass with the best absorber plate is $20 \mathrm{~mm}$.
From the research, more research needs to be done about the amount of cover glass, water flow rate and initial heating plate solar water heater double.

\section{LITERATURE REVIEW}

\subsection{Solar Water Heating}

Solar water heating systems can be broadly divided into three main parts:

1. Solar collector that receive and transfer the sun's radiant energy into thermal energy in the working fluid.

2. System of working fluid channel or pipe diverter, which is the part that connects the collector to the storage.

3. Fluid storage tank that is part of the store and hold hot water.

Based on the shape desired heat temperature heat collector can be broadly grouped into three parts:

1. Centering collector with a low concentration of between $80^{\circ} \mathrm{C}-150^{\circ} \mathrm{C}$

2. Flat plate collectors for temperatures lower than $80^{\circ} \mathrm{C}$

\subsection{Flat Plate Solar Collector}

Solar water heaters generally consist of a thermal conductive material selembaran called absorber plates that connect the pipes carrier heat transfer fluid, usually water. Solar radiation transmitted through transparent pipes and converted into heat in the absorber plate and the bottom and sides isolated. 


\subsection{Collectors Flat Plate Collector Efficiency}

Collector panel efficiency is the ratio between the rates of useful heat (QU) is transferred to a fluid divided by solar radiation on the cover plate. Efficiency can be shown in the equation of Duffie JA and Beckman W.A. (1980), as follows:

$$
\eta_{i}=\frac{Q_{u}}{A_{c} G_{t}}
$$

From the equation above can also use the collector efficiency equation below:

$$
\begin{gathered}
\eta_{i}=F_{R}(\tau \alpha)-F_{R} U_{L} \frac{\left(T_{i}-T_{a}\right)}{G_{t}} \\
\eta_{i}=\frac{\dot{m} C_{P}\left(T_{\text {out }}-T_{\text {in }}\right)}{G_{t} \cdot A_{C}}
\end{gathered}
$$

Description:

$\mathrm{Q}_{\mathrm{u}}=$ The energy absorbed by the collector, $\left(\mathrm{W} / \mathrm{m}^{2}\right)$

$\mathrm{A}_{\mathrm{c}}=$ The size of the collector,,$\left(\mathrm{m}^{2}\right)$

$\mathrm{F}_{\mathrm{R}}=$ Collector heat loss factor

$\mathrm{U}_{\mathrm{L}}=$ Overall heat loss $\left(\mathrm{W} / \mathrm{m}^{2}{ }^{0} \mathrm{C}\right)$

$\mathrm{G}_{\mathrm{t}} \quad=$ Total solar radiation intensity $\left(\mathrm{W} / \mathrm{m}^{2}\right)$

$\mathrm{T}_{\mathrm{i}}=$ The temperature of the incoming water $\left({ }^{0} \mathrm{C}\right)$

$\mathrm{T}_{\text {out }}=$ The temperature of the water out $\left({ }^{0} \mathrm{C}\right)$

$\tau=$ Transmissivity glass cover

$\alpha=$ Absorptivity of absorber plate

\subsection{Older Studies}

Research solar water heater and absorber plates have been made by researchers. Some of them are used as a basis to support the implementation of this study. Bhide et al. (1982), introduces a simple method for comparing the thermal performance of flat plate collectors which is coated with a layer of a known value and power absorption reflected sunlight. This is a simple way to get the value and the right to a certain selection of collector surface. This method shows the limit on the ratio of the inner layer and selects a value and will benefit the total energy used in the selection of a good coating. Rahmad (2001), conducted research on the absorber plate for seawater distillation From some of the materials tested in this study, obtained copper coated with matte black paint types have good heat absorption coefficient, ie 0.82 . In this research, also carried out observations on the performance of solar still with a size of $1 \times 1 \mathrm{~m}$ with the addition of gravel on top of the absorber plate, the test results showed absorber plate with the addition of gravel on top of it has a good efficiency.

Kris and San (2001), parameters that affect the performance of the collector including the thickness of the absorber plate and the distance between the pipes collector called collector fin efficiency. The results showed the thick absorber plates and the smaller the distance between the collector pipes, fin efficiency of the optimum collector.

Anggraini (2001), research was to determine the effect of the temperature range kepelat glass plate stating the heat received. Glass used for research are clear glass and frosted glass with a thickness of $3 \mathrm{~mm}$ each and $5 \mathrm{~mm}$. The results found that the highest temperature is achieved when the glass plate used types of clear glass with a distance of $3 \mathrm{~mm}$ glass into plates $20 \mathrm{~mm}$.

Sambada (2004), circulation water from collector ketangki the IAR solar heating termosifon occur naturally, due to differences in the type of water dikolektor times with water in the tank so it does not require a pump, but kerjanyanya performance can be better than a solar water heating system pump receipts. Research using simulation graph $f$ that was used to estimate the performance of the water heating system with forced circulation pump The simulation shows the number and wide collector, the number of daily hot water use and the volume of water in storage tanks affect the fraction of solar water heating systems termosifon.

Rahardjo (2005), using two glass cover obtained better efficiency than using only one glass. The temperature difference between the water out into the collector and the collector glass cover with 2 layers could be higher by about 17 ${ }^{\circ} \mathrm{C}$ compared to the collector with a glass cover.

Ismail (2005), water flow rate on the solar heater, the faster the flow, the resulting warm water has a lower temperature, and the type of solar water heating collectors flat plate collectors with tilt angle $0^{\circ}$ produces the optimum water temperature is by average temperature of $59375^{\circ} \mathrm{C}$ and a maximum temperature of $71^{\circ} \mathrm{C}$.

Farid and Ismail (2006), the amount of glass cover three layers with a thickness of $5 \mathrm{~mm}$ produce high efficiency solar water heater is higher than using one or two layers.

Mustafa (2006), The efficiency of absorption of solar heat on the double plate heater is higher than the efficiency of conventional heater solar heat absorption and heat absorption efficiency of the (Ti-Ta) / Gt dual plate solar heater decline more sharply than a conventional diesel heater.

Ismail (2007), examined the rate of water flow in a simple solar heater using a single absorber plate, resulting in the faster the flow rate the performance of solar water heater produces lower.

Ismail (2008), examined the absorber plate absorber double and single use concrete in a simple solar water heater, solar water heater efficiencies simple dual absorber plate is higher than single absorber plate. 
Mustafa (2009), In each test variation of the flow rate on the heat absorption efficiency solar heater double plate is higher than the efficiency of absorption of solar heat and a conventional heater temperature solar water heater plate out double in the afternoon decline is slower than the temperature of the water out of conventional solar heater .

Farid and Ismail (2010), concrete absorber plate waveform generating efficiency of solar water heater is higher than flat plate absorber.

\section{METHODS}

\subsection{Stages of Research}

Based on the background research on innovative solar water heater, this study originated from the research that has been done, either by the lead researcher, a research as well as by other researchers. From these studies, then conducted research to analyze the amount of cover glass double plates The number of glass cover slip testing is one layer, two layers and three layers. The best results of testing the amount of glass followed by analyzing the flow rate of the working fluid and the most recent test analysis preheat the working fluid to see the maximum performance of solar water heater. At each stage of testing and data collection, and performed data processing, graphed, analyzed and then summarized.

\subsection{Research Tools}

Research equipment using solar heater plate collectors dual, namely:

- Absorber plate of aluminum with a thickness of $3 \mathrm{~mm}$ and painted matte black.

- Plate heat storage of PVC, thickness $10 \mathrm{~mm}$.

- Glass covers $5 \mathrm{~mm}$ thick one side and north-facing orientation.

- The distance between the absorber plate and the storage by

$20 \mathrm{~mm}$

- Insulation of $3 \mathrm{~cm}$ thick Styrofoam material.

- Angle Glass 150.

- Drains using PVC pipe $25.4 \mathrm{~mm}$.

- Pump using aquarium pump

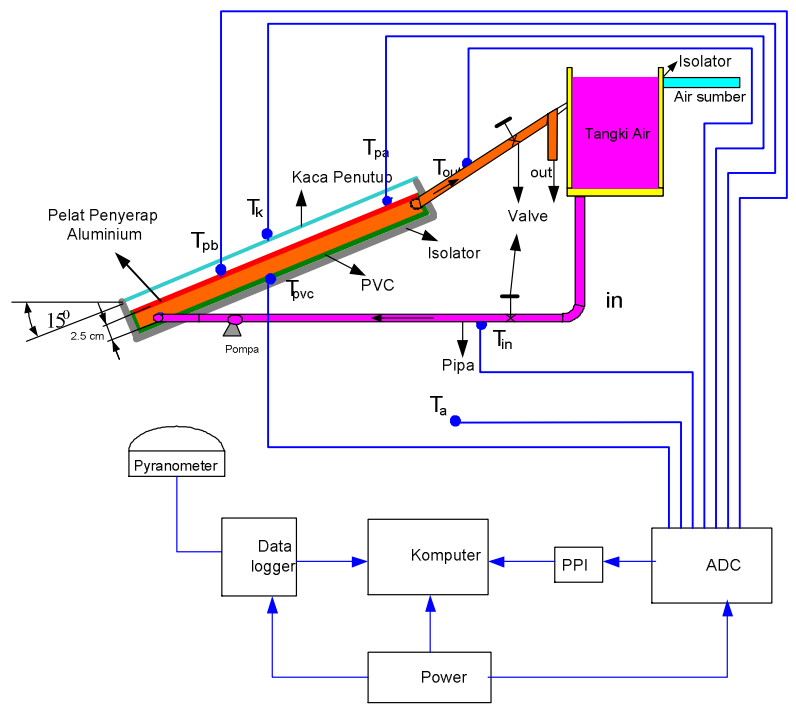

Figure1. Schematic experimental tools solar water heater (side view)

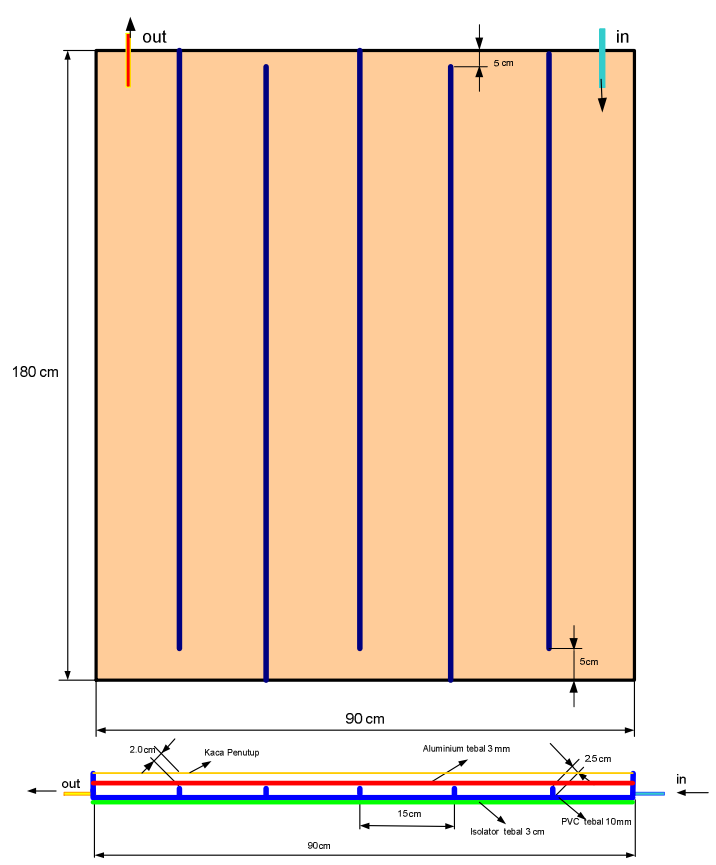

Figure2. Schematic experimental tools absorber plate and zigzag grooves (top)

\subsection{The Testing Procedure}

Observations were made starting at 10.00 WIB until 14.00 WIB (peak time) directly under the sun with the duration of data recording is done every 10 minutes. Laboratory testing location in Solar and Alternative Energy Department of Mechanical Engineering Faculty of Engineering University of Brawijaya Malang 


\begin{tabular}{|c|c|c|}
\hline Testing & Outcome & Indicator \\
\hline $\begin{array}{l}\text { The number of } \\
\text { double glass cover } \\
\text { plate }\end{array}$ & $\begin{array}{l}\text { Retrieved amount } \\
\text { of cover glass with } \\
\text { a solar water } \\
\text { heater efficiency } \\
\text { of the highest }\end{array}$ & \multirow[t]{3}{*}{$\begin{array}{l}\text { Scientific } \\
\text { articles / } \\
\text { National Journal } \\
\text { / Proceedings }\end{array}$} \\
\hline $\begin{array}{l}\text { The flow rate of } \\
\text { the working fluid } \\
\text { using a number of } \\
\text { the best double } \\
\text { glass cover plate }\end{array}$ & $\begin{array}{l}\text { Retrieved working } \\
\text { fluid flow rate } \\
\text { efficiency solar } \\
\text { water heater with } \\
\text { the highest }\end{array}$ & \\
\hline $\begin{array}{l}\text { preheat the } \\
\text { working fluid } \\
\text { using a flow rate } \\
\text { of the working } \\
\text { fluid and the } \\
\text { number of double } \\
\text { plate glass cover } \\
\text { best }\end{array}$ & $\begin{array}{l}\text { Retrieved } \\
\text { maximum } \\
\text { efficiency of solar } \\
\text { water heater }\end{array}$ & \\
\hline
\end{tabular}

\section{RESULTS AND DISCUSSION}

\subsection{Testing Total Absorbent Glass Cover Plates Dual}

\section{use}

The data taken in this study to test the amount of glass cover plate solar heater consists of multiple solar radiation intensity, water temperatures are in, the water temperatures are out, the temperatures are absorber plate, glass cover temperature and ambient temperature. Data recording is done every 10 minutes to determine the time of data storage on DAI software. Furthermore, the data is calculated, graphed and analyzed.

1. Temperature and total solar radiation intensity average From the test result data can be graphed average temperature and total solar radiation intensity on the average number of glass cover testing as follows:

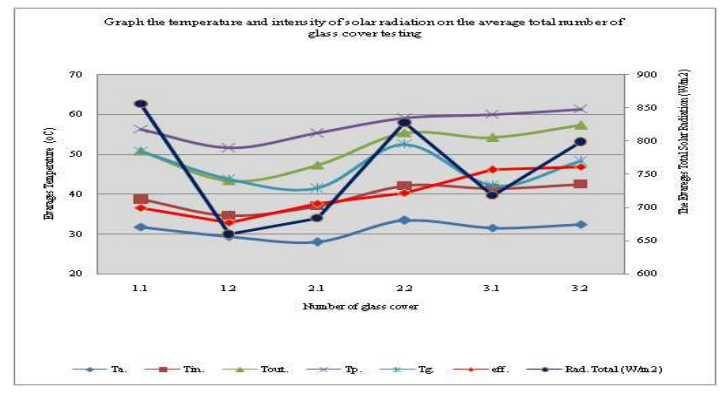

Description:

$1.1=$ Tests using 1 piece of glass cover the first day

$1.2=$ Tests using 1 piece of glass cover day two

$2.1=$ Tests using 2 pieces of glass cover the first day

$2.2=$ Tests using 2 pieces of glass cover day two
$3.1=$ Tests using 3 pieces of glass cover the first day

$3.2=$ Tests using 3 pieces of glass cover day two

Figure3. Graph the temperature and intensity of solar radiation on the average total number of glass cover testing

Solar radiation recorded by the data logger via pyranometer during the test varies, so does the temperature of glass cover, absorber plate temperature, ambient temperature, air temperature and water temperature go out. Data obtained from 10:00 am until 14:00 in total then averaged and the result can be seen in Figure 3. From the graph looks the intensity of total solar radiation on average have the same pattern as the average temperature (temperature of glass cover, absorber plate temperature, the temperature of the incoming water temperature and water out). Thus the amount of energy absorbed by the solar water heater will be in accordance with the energy source is solar radiation. For not all of the same ambient temperature with solar radiation pattern, it is because there are other factors that affect the temperature, the wind speed and humidity.

\section{The Efficiency of Heat Absorption Test Using a Number of Glass Cover Plate Solar Water Heater Double}

From the research then calculated double plate solar water heater using equation Kreith, 1982, 56 and Duffie, 1980, 252. Sample calculations using cover glass number one fruit as follows:

$$
\begin{aligned}
\dot{m} & =0.01 \mathrm{~kg} / \text { detik } \\
\mathrm{C}_{\mathrm{p}} & =4100 \mathrm{~J} / \mathrm{kg} \cdot{ }^{\circ} \mathrm{C} \\
\mathrm{T}_{\text {in }} & =37.82{ }^{\circ} \mathrm{C} \\
\mathrm{T}_{\text {out }} & =46.45^{\circ} \mathrm{C} \\
\mathrm{A}_{\mathrm{c}}= & 1.62\left(\mathrm{~m}^{2}\right) \\
\mathrm{G}_{\mathrm{t}} & =918.98\left(\mathrm{~W} / \mathrm{m}^{2}\right) \\
& \eta_{i}=\frac{\dot{m} \times \mathrm{Cp} \times(\text { Tout }-\mathrm{Tin})}{G_{t} \cdot A_{C}} \times 100 \% \\
& \eta_{i}=\frac{0.01 \times 4100 \times(46.45-37.82)}{918.98 \times 1.62} \times 100 \% \\
& \eta_{i}=23.77 \%
\end{aligned}
$$

These calculations (Ti-Ta) / Gt dual plate solar heater, as follows:

Given:

$$
\begin{aligned}
\mathrm{T}_{\text {in }} & =37.82{ }^{\circ} \mathrm{C} \\
\mathrm{T}_{\mathrm{a}} & =31.48{ }^{\circ} \mathrm{C} \\
\mathrm{G}_{\mathrm{t}} & =918.98\left(\mathrm{~W} / \mathrm{m}^{2}\right) \\
\frac{(T i-T a)}{G_{t}} & =\frac{(37.82-31.48)}{918.98} \\
\frac{(T i-T a)}{G_{t}} & =0.007
\end{aligned}
$$


From the results of these calculations can be made connection graph of the efficiency of solar water heater (Ti-Ta) / Gt. as follows:

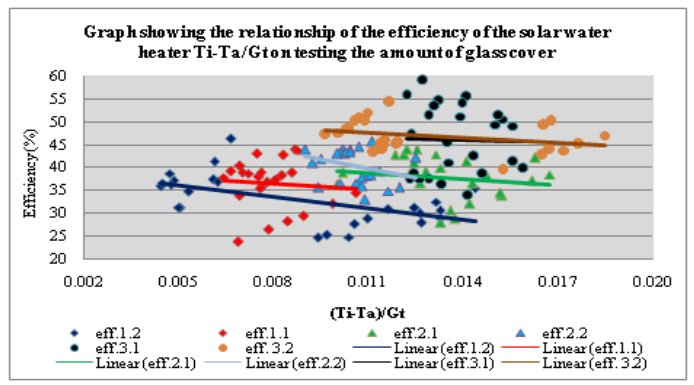

Figure4. Graph showing the relationship of the efficiency of the solar water heater $\mathrm{Ti}-\mathrm{Ta} / \mathrm{Gt}$ on testing the amount of glass cover

From the graph above it can be seen the efficiency of solar water heater double plate glass cover with the number three can produce high efficiency solar water heater, higher efficiency and more gentle decline compared with the efficiency of the solar water heater with cover glass number one and two. This condition is caused by a glass cover that serves as transmisifitas energy solar radiation and also serves as an insulator, so the number three glass cover can improve the efficiency of solar water heater.

\subsection{Flow Rate Testing with Three Fruit Absorbent}

\section{Glass Cover Plates Dual use}

From the results of testing the amount of glass that best cover the amount of 3 pieces of cover glass used in the testing of water flow rate. From the data obtained is then calculated, and the results can be graphed.

\section{Temperature and intensity of solar radiation on} average total flow rate testing

Data from the test results, it can be graphed the average temperature and the intensity of total solar radiation on the average water flow rate testing, as follows:

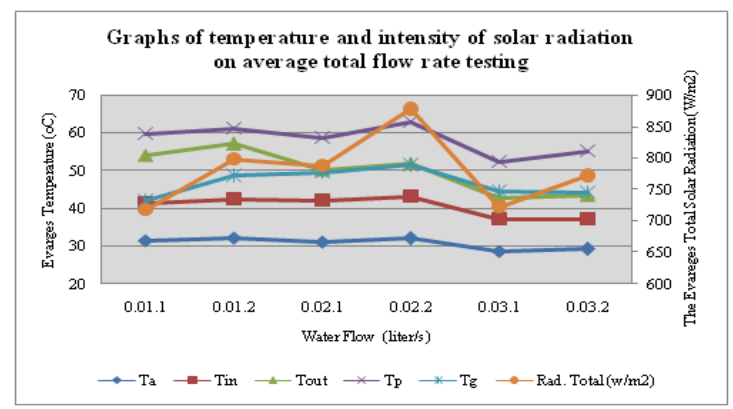

Description:

0.01.1 Tests using flow rate $=0.01$ (liters $/ \mathrm{s}$ ) the first day
0.01.2 Tests using flow rate $=0.01$ (liters $/ \mathrm{s}$ ) Second Day 0.02 .1 Tests using flow rate $=0.02$ (liters $/ \mathrm{s}$ ) the first day 0.02.2 Tests using flow rate $=0.02$ (liters $/ \mathrm{s}$ ) Second Day 0.03.1 Tests using flow rate $=0.03$ (liters $/ \mathrm{s}$ ) the first day 0.03.2 Tests using flow rate $=0.03$ (liters $/ \mathrm{s}$ ) Second Day

Figure5.graphs of temperature and intensity of solar radiation on average total flow rate testing

Solar radiation recorded by the data logger via pyranometer during the test varies, so does the temperature of glass cover, absorber plate temperature, ambient temperature, air temperature and water temperature go out. Data obtained from 10:00 am until 14:00 in total then averaged and the result can be seen in Figure 5. From the graph looks the intensity of solar radiation on average total have the same pattern with the average temperature (temperature of glass cover, absorber plate temperature, ambient temperature, air temperature and water temperature $\log$ out). Thus the amount of energy absorbed by the solar water heater will be in accordance with the energy source is solar radiation. Decline in the average temperature is more visible on the test flow rate of 0:03 liters / $\mathrm{s}$ compared to the rate of water flow underneath.

\section{Efficiency of solar water heater at the test flow rate of water using solar water heater with three double plate glass cover}

From the research then calculated using a multiple plate solar heater equation Kreith, 1982, 56 and Duffie, 1980, 252, and the results can be seen in the following graph:

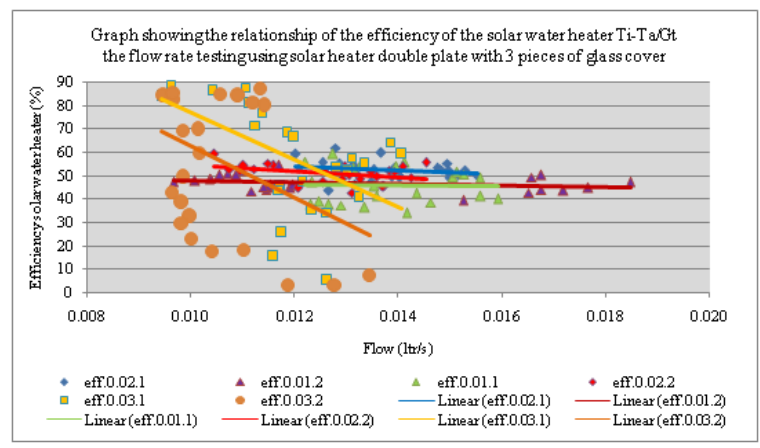

Figure6. Graph showing the relationship of the efficiency of the solar water heater $\mathrm{Ti}-\mathrm{Ta} / \mathrm{Gt}$ the flow rate testing using solar heater double plate with 3 pieces of glass cover

From the graph above it can be seen the efficiency of solar water heater double plate with flow 0:03 ltr / s using three the number of cover glass to produce high efficiency solar water heater, higher efficiency and decreased more sharply than the efficiency of the solar water heater with a water flow rate of 0:01 $\mathrm{ltr} / \mathrm{s}$ and 0:02 $\mathrm{ltr} / \mathrm{s}$. This condition is caused by the flow rate itself, in which the flow rate in the calculation as a multiplier, so the efficiency of the solar water heater is higher, 
but the decline in the efficiency of the solar water heater (TiTa) / Gt sharper.

\subsection{Initial testing using a plate absorber double heating}

This test uses preheated $30{ }^{\circ} \mathrm{C}, 40{ }^{\circ} \mathrm{C}, 50{ }^{\circ} \mathrm{C}$ and $60{ }^{\circ} \mathrm{C}$ with a solar water heater equipment uses three pieces / layers of glass cover with different flow rates $(0.01(1 / \mathrm{s}), 0.02(1 / \mathrm{s})$ and 0.03 (liter / s)).

\section{Temperature and Solar Radiation Intensity Total average on Warm Early Testing}

From the data pre-heating test results, can be graphed average temperature and total solar radiation intensity average preheating testing, as follows:

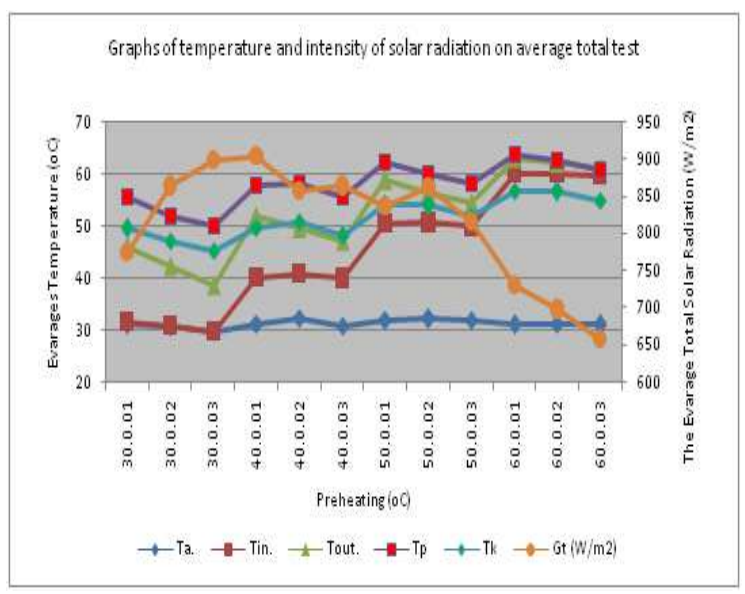

Description:

30.0.01 Testing preheating $=30{ }^{\circ} \mathrm{C}$ with a flow rate of 0.01 (liters / s)

30.0.02 Testing preheating $=30 \mathrm{oC}$ with a flow rate of 0.02 (liters / s)

30.0.03 Testing preheating $=30 \mathrm{oC}$ with a flow rate of 0.03 (liters / s)

40.0.01 Testing preheating $=40^{\circ} \mathrm{C}$ with the flow rate of 0.01 (liters / s)

40.0.02 Testing preheating $=40^{\circ} \mathrm{C}$ with the flow rate of 0.02 (liters / s)

40.0.03 Testing preheating $=40^{\circ} \mathrm{C}$ with the flow rate of 0.03 (liters / s)

50.0.01 Testing preheating $=50{ }^{\circ} \mathrm{C}$ with a flow rate of 0.01 (liters / s)

50.0.02 Testing preheating $=50{ }^{\circ} \mathrm{C}$ with a flow rate of 0.02 (liters / s)

50.0.03 Testing preheating $=50^{\circ} \mathrm{C}$ with a flow rate of 0.03 (liters / s)

60.0.01 Testing preheating $=60^{\circ} \mathrm{C}$ with a flow rate 0.01 (liters / s)

60.0.02 Testing preheating $=60^{\circ} \mathrm{C}$ with a flow rate 0.02 (liters / s)
60.0.03 Testing preheating $=60^{\circ} \mathrm{C}$ with a flow rate 0.03 (liters / s)

Figure7 Graphs of temperature and intensity of solar radiation on average total test

Solar radiation recorded by the data logger via pyranometer during testing is quite varied, so did the temperature of the glass cover, absorber plate temperature, ambient temperature, temperature of the incoming water temperature and water out. Data obtained from 10:00 am until 14:00 in total then averaged and the result can be seen in chart 5.5. From the graph looks the intensity of total solar radiation on average have the same pattern with an average ambient temperature, but the temperature of the glass cover, absorber plate temperature, the temperature of the incoming water temperature and water out different patterns. These conditions are caused by pre-heating the water in the reservoir. Preheating water in a given reservoir will result in a rise in water temperature into the solar water heater system. His influence will be seen in the temperature of the absorber plate a sharper decline, especially with the rate of change in the flow of incoming water. The greater the addition of hot water gets inside the tank to $60{ }^{\circ} \mathrm{C}$ decrease in temperature will cause the absorber plate and the water is getting smaller.

2 The efficiency of the solar water heater preheats incoming water testing (in the reservoir) using dual plate solar water heater

From the research then calculated using a multiple plate solar heater equation Kreith, 1982, 56 and Duffie, 1980, 252, and the results can be seen in the following graph:

From the results of these calculations can be made connection graph of the efficiency of solar water heater (Ti-Ta) / Gt. as follows

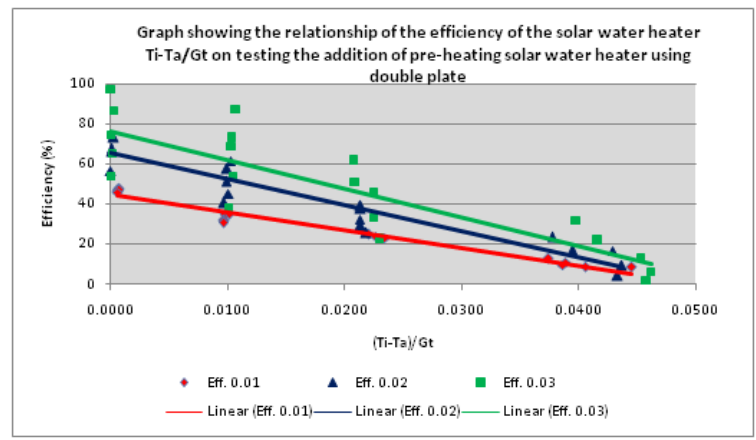

Figure8. Graph showing the relationship of the efficiency of the solar water heater Ti-Ta/Gt on testing the addition of preheating solar water heater using double plate

From the graph above it can be seen the efficiency of solar water heater, dual plate preheat the incoming water to $30 \mathrm{oC}$ has a higher efficiency than the preheater $40 \mathrm{oC}, 50 \mathrm{oC}$ and 60 
$\mathrm{oC}$, and it all happens at all flow rates. Thus, the incoming water temperature greatly affect the efficiency of the solar water heater and water inlet temperature the greater the efficiency of the solar water heater efficiency approaches zero, the temperature of the water in and out relatively the same.

\section{DISCUSSION}

Of testing the amount of cover glass to look more and more layers of glass cover up to three layers of lead abatement transmissivity is relatively small, and the function of the larger glass as an insulator. Such conditions can reduce the heat of solar water heater equipment that comes out through the glass cover to the environment, this increasing the efficiency of solar water heater.

From the test results of water flow rate, the greater the flow rate of water through 0:03 $1 \mathrm{tr} / \mathrm{s}$, the efficiency of solar water heater increases. This condition is caused by the equation, where the rate of water flow is used as a multiplier, so the efficiency of solar water heater increases.

From the results of initial testing of incoming water heating located within the reservoir, the greater the warming seen in the reservoir water temperature absorber plate out and the temperature is relatively the same. These conditions lead to high efficiency solar water heater close to zero. And with a variety of flow rates, there was a similar pattern, there is a difference scale efficiency of solar water heater. Where the greater the flow rate the greater the efficiency of solar water heater, because the flow rate is used as a multiplier in the equation system.

\section{CONCLUSIONS}

From the results of the study can be summarized as follows:

1 Efficiency of Solar Water Heater is best to cover the amount of three layers of glass compared to the amount of cover glass and one layer of the bilayer.

2. The greater the water flow rate, the efficiency of the solar water heater increases.

3. early heating on the incoming water, causing the water exit temperature and the temperature of the absorber plate is relatively the same, so the efficiency of the solar water heater close to zero

\section{REFERENCES}

[1] Arismunandar. W (1995), Teknologi Rekayasa Surya, PT. Pradnya Paramita.

[2] Anggaraini E. H. (2001), Pengaruh jarak kaca ke pelat terhadap panas yang diterima suatu kolektor surya pelat datar, Jurnal Teknik Mesin, Universitas Kristen Petra.

[3] Bhide V. G. et. al, (1982)., Choice of selective coating for flat collector, solar energy, Vol. 29, No.6, pp. 463-465.
[4] Duffie J.A. dan Beckman W.A. (1980), Solar Engineering Of Thermal Processes. New York : John Willey \& Sons.

[5] Farid A. dan Ismail N.R (2006), Pengaruh jumlah kaca penutup dan volume air terhadap kinerja solar heater sederhana, PHK-A2. Teknik Mesin. Universitas Widyagama Malang.

[6] Holman J.P. (1995), Perpindahan Kalor , Jakarta : Penerbit Erlangga.

[7] Ismail N.R (2005), Kecepatan aliran air pada solar water heater, LPPM. Universitas Widyagama Malang.

[8] Ismail N.R (2007), Pengaruh jenis pelat penyerap dan laju aliran terhadap kinerja solar heater sederhana, PHK-A2. Teknik Mesin. Universitas Widyagama Malang.

[9] Ismail N.R (2008), Pengaruh pelat penyerap ganda dan tunggal menggunakan beton cor terhadap kinerja solar heater sederhana, LPPM. Teknik Mesin. Universitas Widyagama Malang.

[10] Farid A. dan Ismail N.R (2010), Pengaruh pelat penyerap bentuk gelombang dan reflektor terhadap kinerja solar heater sederhana, PDM 2010 Teknik Mesin. Universitas Widyagama Malang.

[10] Kreith F and Kreider. F. Jan. "Solar Heating And Cooling Active And Passive Desing". New York : McGraw-Hill.

[12] Mustafa (2008), Studi eksperimen perbandingan kolektor pelat ganda dan kolektor konvensional terhadap kinerja solar water heater. Thesis, Pascasarjana Unibraw Malang

[13] Mustafa (2009), Pengaruh pelat ganda dan laju aliran air terhadap kinerja solar water heater, PDM-Dikti.

[14] Rahardjo T. dan Ekadewi A.H., "Unjuk Kerja Pemanas Air Jenis Kolektor Surya Plat Datar dengan Satu dan Dua Kaca Penutup", Jurusan Teknik Mesin - Universitas Kristen Petra

[15] Sambada R.FA (2004), "Fraksi Surya Pemanas Air Surya Termosifon", Prosiding, Seminar Nasional, Pengembangan Riset dan Teknologi dibidang industri. Jurusan Teknik Mesin - Universitas Sanata Dharma Yogyakarta

[16] Kristanto P. dan San Y.K., (2001), Pengaruh Tebal Pelat Dan Jarak Antar Pipa Terhadap Performansi Kolektor Surya Pelat Datar, Jurnal Teknik Mesin, Universitas Kristen Petra.

[17] Rahmad Subarkah (2001), "Penelitian Absorber Solar Still Untuk Distilasi Air Laut", Skripsi, Malang: JurusanTeknik Mesin FT Unibraw Malang 